\title{
AARP
}

\section{AARP Arizona Work \& Save Survey: Hispanic/Latino Registered Voters Annotated Questionnaire}

\section{October 2021}

Market: Hispanic/Latinos in Arizona

Screening Criteria: Hispanic/Latino resident of Arizona, ages 25-64, registered voter in Arizona, employed or unemployed and looking for work

Mode: Telephone survey

Sample: $\mathrm{n}=317$

*Percentages may not add up to $100 \%$ due to rounding

\section{Screening Questions}

QS1. [All] Our study is interested in the opinions of certain age groups. Could you please tell me your age as of your last birthday? [IN YEARS] [AGE CODED]

\begin{tabular}{|c|l|}
\hline$\%$ & $\mathrm{n}=317$ \\
\hline 0 & Under 25 [TERMINATE] \\
\hline 33 & $25-34$ \\
\hline 36 & $35-49$ \\
\hline 13 & $50-55$ \\
\hline 18 & $56-64$ \\
\hline 0 & 65 or older [TERMINATE] \\
\hline 0 & Refused [TERMINATE] \\
\hline
\end{tabular}

QS2. [All] And just to confirm, are you a resident of Arizona?

\begin{tabular}{|c|l|}
\hline$\%$ & $\mathrm{n}=317$ \\
\hline 100 & Yes \\
\hline 0 & $\begin{array}{l}\text { No [ASK FOR RESIDENT IN HH; TERMINATE IF NO ONE IN AVAILABLE IN HH } \\
\text { IS 25-64 AND A RESIDENT OF ARIZONA] }\end{array}$ \\
\hline
\end{tabular}

QS3. [All] What is your 5-digit ZIP code? AGE 25-64 RESIDENT OF ARIZONA]

QS4. [All] And are you registered to vote in Arizona?

\begin{tabular}{|c|l|}
\hline$\%$ & $\mathrm{n}=317$ \\
\hline 100 & Yes \\
\hline 0 & No [TERMINATE] \\
\hline 0 & Not sure/ Don't know (DO NOT READ) [TERMINATE] \\
\hline 0 & Refused (DO NOT READ) [TERMINATE] \\
\hline
\end{tabular}


QS5. [AII] To ensure it is recorded accurately, could you please state your gender?

\begin{tabular}{|c|l|}
\hline$\%$ & $\mathrm{n}=317$ \\
\hline 52 & Male \\
\hline 48 & Female \\
\hline 0 & Other (specify) \\
\hline
\end{tabular}

QS6. Which of the following best describes your current employment status? Are you...? [READ EACH ANSWER CATEGORY]

\begin{tabular}{|c|l|}
\hline$\%$ & $n=317$ \\
\hline 29 & Self-employed full-time \\
\hline 4 & Self-employed part-time \\
\hline 54 & Employed full-time \\
\hline 5 & Employed part-time \\
\hline 0 & Retired and not working at all [TERMINATE] \\
\hline 8 & Unemployed and looking for work [SKIP TO Q1] \\
\hline 0 & Or are you not in the labor force for other reasons [TERMINATE] \\
\hline 0 & Not sure/ Don't know (DO NOT READ) [TERMINATE] \\
\hline 0 & Refused (DO NOT READ) [TERMINATE] \\
\hline
\end{tabular}

QS7. SCREEN OUT GOV'T WORKERS [IF QS6=1, 2, 3, OR 4, CONFIRM/ASK] Are you currently employed in a federal, state, or local government job?

\begin{tabular}{|c|l|}
\hline$\%$ & $\mathrm{n}=292$ \\
\hline 0 & Yes [TERMINATE] \\
\hline 100 & No \\
\hline 0 & Not sure/ Don't know (DO NOT READ) [TERMINATE] \\
\hline 0 & Refused [TERMINATE] \\
\hline
\end{tabular}

\section{Main}

A1. [All] In general, are you worried or not worried about the coronavirus pandemic? Is that (very or somewhat worried)/(not too or not at all worried)?

\begin{tabular}{|c|l|}
\hline$\%$ & $\mathrm{n}=317$ \\
\hline 38 & Very worried \\
\hline 41 & Somewhat worried \\
\hline 10 & Not too worried \\
\hline 10 & Not at all worried \\
\hline$<1$ & Not sure (DO NOT READ) \\
\hline 0 & Refused (DO NOT READ) \\
\hline
\end{tabular}


A2. [All] When you think about the coronavirus pandemic, how worried are you about.....? (READ LIST) Is that (very or somewhat worried)/(not too or not at all worried)? [RANDOMIZE]

\begin{tabular}{|l|c|c|c|c|c|c|}
\hline \multicolumn{1}{|c|}{$\mathrm{n}=317$} & $\begin{array}{c}\text { Very } \\
\text { worried } \\
\%\end{array}$ & $\begin{array}{c}\text { Somewhat } \\
\text { worried } \\
\%\end{array}$ & $\begin{array}{c}\text { Not too } \\
\text { worried } \\
\%\end{array}$ & $\begin{array}{c}\text { Not at } \\
\text { all } \\
\text { worried } \\
\%\end{array}$ & $\begin{array}{c}\text { Don't } \\
\text { know } \\
\%\end{array}$ & $\begin{array}{c}\text { Refused } \\
\%\end{array}$ \\
\hline $\begin{array}{l}\text { A. Your current personal financial } \\
\text { situation }\end{array}$ & 36 & 31 & 18 & 15 & 1 & 0 \\
\hline $\begin{array}{l}\text { B. Your long-term personal financial } \\
\text { situation over the next 5 years }\end{array}$ & 36 & 34 & 14 & 15 & 1 & 0 \\
\hline $\begin{array}{l}\text { C. Your health or the health of } \\
\text { others in your family }\end{array}$ & 45 & 35 & 9 & 11 & 1 & $<1$ \\
\hline $\begin{array}{l}\text { D. The security of your job or the } \\
\text { job of someone in your family }\end{array}$ & 33 & 31 & 16 & 18 & 2 & $<1$ \\
\hline
\end{tabular}

1. [All] As you think about your finances in the future, how anxious do you feel about having enough money to live comfortably through your retirement years? Are you...? [READ EACH ANSWER CATEGORY]

\begin{tabular}{|c|l|}
\hline$\%$ & $\mathrm{n}=317$ \\
\hline 38 & Very anxious \\
\hline 37 & Somewhat anxious \\
\hline 16 & Not very anxious \\
\hline 8 & Not anxious at all \\
\hline 1 & Not sure/ Don't know [DO NOT READ] \\
\hline 0 & Refused [DO NOT READ] \\
\hline
\end{tabular}

2_A. [If ages 25-34] Given the amount of money you currently have saved, do you think you'll be able to save enough money for your retirement years?

\begin{tabular}{|l|l|}
\hline$\%$ & $\mathrm{n}=103$ \\
\hline 48 & Yes \\
\hline 35 & No \\
\hline 17 & Not sure/ Don't know [DO NOT READ] \\
\hline 0 & Refused [DO NOT READ] \\
\hline
\end{tabular}

2_B. [If ages 35-64] Given the amount of money you currently have saved, do you wish you had more money saved for your retirement years?

\begin{tabular}{|c|l|}
\hline$\%$ & $\mathrm{n}=214$ \\
\hline 90 & Yes \\
\hline 10 & No \\
\hline 1 & Not sure/ Don't know [DO NOT READ] \\
\hline 0 & Refused [DO NOT READ] \\
\hline
\end{tabular}




\section{AARP}

3. [All] How confident are you that you will have enough money to take care of your healthcare expenses during your retirement years? These expenses include things such as co-payments, deductibles, out-of-pocket drug costs, expenses that Medicare doesn't cover, such as hearing aids and eyeglasses, and possibly nursing home or long-term care. Are you...? [READ EACH ANSWER CATEGORY]

\begin{tabular}{|c|l|}
\hline$\%$ & $\mathrm{n}=317$ \\
\hline 23 & Very confident \\
\hline 40 & Somewhat confident \\
\hline 17 & Not very confident \\
\hline 18 & Not confident at all \\
\hline 2 & Not sure/ Don't know [DO NOT READ] \\
\hline 0 & Refused [DO NOT READ] \\
\hline
\end{tabular}

4. [All] How concerned are you that cost-of-living increases (over which you have no control) may reduce your standard of living? Are you...? [READ EACH ANSWER CATEGORY]

\begin{tabular}{|c|l|}
\hline$\%$ & $n=317$ \\
\hline 45 & Very concerned \\
\hline 43 & Somewhat concerned \\
\hline 8 & Not very concerned \\
\hline 4 & Not concerned at all \\
\hline 1 & Not sure/ Don't know [DO NOT READ] \\
\hline 0 & Refused [DO NOT READ] \\
\hline
\end{tabular}

5. [All] How important is it for people to be able to save money for their retirement years while they are working? [READ EACH ANSWER CATEGORY]

\begin{tabular}{|c|l|}
\hline$\%$ & $n=317$ \\
\hline 76 & Very important \\
\hline 22 & Somewhat important \\
\hline$<1$ & Not very important \\
\hline 1 & Not important at all \\
\hline 0 & Not sure/ Don't know [DO NOT READ] \\
\hline$<1$ & Refused [DO NOT READ] \\
\hline
\end{tabular}

6. [All] When it comes to planning and saving for retirement, would you say that you are ahead of schedule, on track, or behind schedule?

\begin{tabular}{|c|l|}
\hline$\%$ & $\mathrm{n}=317$ \\
\hline 8 & Ahead of schedule \\
\hline 49 & On track \\
\hline 42 & Behind schedule \\
\hline 1 & Not sure/ Don't know [DO NOT READ] \\
\hline$<1$ & Refused [DO NOT READ] \\
\hline
\end{tabular}




\section{AARP}

7. [READ ONLY IF QS6=3-4 EMPLOYED, ASK] Which of the following ways to save for retirement does your current employer provide... do they provide? [MULTIPLE RESPONSES ALLOWED ROTATE A AND B] [READ EACH ANSWER CATEGORY]

\begin{tabular}{|c|l|}
\hline$\%$ & $\mathrm{n}=187$ \\
\hline 32 & $\begin{array}{l}\text { A. A traditional pension plan or a defined benefit plan? [IF ASKED: "A defined } \\
\text { benefit plan supplies retirees with a monthly income, typically based on a formula of } \\
\text { salary and years of service. It is not a 401( } \mathrm{k}) \text { plan."] }\end{array}$ \\
\hline 61 & $\begin{array}{l}\text { B. An IRA, 401(k) or 403(b) defined contribution plan? [IF ASKED: "A defined } \\
\text { contribution plan allows you to make contributions from your salary to an individual } \\
\text { account set up in your name."] }\end{array}$ \\
\hline 18 & C. Or your employer does NOT offer a way to save for retirement. \\
\hline 4 & Not sure/ Don't know [DO NOT READ] \\
\hline 0 & Refused [DO NOT READ] \\
\hline
\end{tabular}

7A. [READ ONLY IF 7C = yes (EMPLOYER DOES NOT OFFER), not sure or refused] If your employer offered a way to save for retirement at work how likely would you take advantage of it? [READ EACH ANSWER CATEGORY] *this question will be asked on a small sample base*

\begin{tabular}{|c|l|}
\hline$\%$ & $\mathrm{n}=41^{*}$ \\
\hline 86 & Very likely \\
\hline 9 & Somewhat likely \\
\hline 3 & Not very likely \\
\hline 3 & Not at all likely \\
\hline 0 & Not sure/ Don't know [DO NOT READ] \\
\hline 0 & Refused [DO NOT READ] \\
\hline
\end{tabular}

* Note small base. Use caution when generalizing to the larger Hispanic/Latino registered voter population in Arizona.

8. Are you making regular contributions to any of the following savings tools...? [ROTATE A-B/B-A, READ C LAST]

\begin{tabular}{|l|c|c|c|c|}
\hline \multicolumn{1}{|c|}{$\mathrm{n}=317$} & $\begin{array}{c}\text { Yes } \\
\%\end{array}$ & $\begin{array}{c}\text { No } \\
\%\end{array}$ & $\begin{array}{c}\text { Not sure } \\
\%\end{array}$ & $\begin{array}{c}\text { Refused } \\
\%\end{array}$ \\
\hline $\begin{array}{l}\text { A. [READ ONLY IF Q7C = YES] A workplace retirement } \\
\text { savings plan such as a 401k or 403b offered by your } \\
\text { employer ( } \mathrm{n}=114)\end{array}$ & 80 & 19 & 1 & 0 \\
\hline $\begin{array}{l}\text { B. [All] A personal retirement savings plan such as an } \\
\text { IRA or thrift savings plan }\end{array}$ & 49 & 49 & 2 & 0 \\
\hline C. [All] Something else to help you save for retirement & 51 & 46 & 3 & $<1$ \\
\hline
\end{tabular}

9. [All] How concerned are you as a taxpayer that some Arizona workers have not saved enough money for retirement and could end up being reliant on public assistance programs? Are you...? [READ EACH ANSWER CATEGORY]

\begin{tabular}{|c|l|}
\hline$\%$ & $\mathrm{n}=317$ \\
\hline 43 & Very concerned \\
\hline 42 & Somewhat concerned \\
\hline 8 & Not very concerned \\
\hline 7 & Not concerned at all \\
\hline$<1$ & Not sure/ Don't know [DO NOT READ] \\
\hline 0 & Refused [DO NOT READ] \\
\hline
\end{tabular}




\section{AARP}

10. Many in Arizona, especially those who work for small businesses, do not have a way to save for retirement at work. One way to help more workers save would be for Arizona to set up a retirement savings program. The program offers workers control over their retirement savings by allowing them to choose whether or not to participate, decide how much to contribute, and let them take their account with them if they change jobs. Workers save for retirement using money automatically taken out of their regular paycheck. The program would be managed as a publicprivate partnership. Do you support or oppose this program? Is that strongly or somewhat? (SELECT ONE ANSWER)

\begin{tabular}{|c|l|}
\hline$\%$ & $\mathrm{n}=317$ \\
\hline 37 & Strongly support \\
\hline 44 & Somewhat support \\
\hline 7 & Neither support not oppose (DO NOT READ) \\
\hline 3 & Somewhat oppose \\
\hline 5 & Strongly oppose \\
\hline 4 & Not sure/ Don't know [DO NOT READ] \\
\hline$<1$ & Refused [DO NOT READ] \\
\hline
\end{tabular}

11. Now l'm going to read a list of some features that could be considered for an Arizona retirement savings program and l'd like you tell me how important each would be to you. After I finish reading each statement, tell me if that feature is very important to you, somewhat important, not very important, or not at all important to you. ...... How important is it to you that an Arizona savings program be...[READ QUESTION FOR ITEM A-D; RANDOMIZE A-D AND READ ALL ITEMS]?

\begin{tabular}{|l|c|c|c|c|c|c|}
\hline \multicolumn{1}{|c|}{$\mathrm{n=317}$} & $\begin{array}{c}\text { Very } \\
\text { important } \\
\%\end{array}$ & $\begin{array}{c}\text { Somewhat } \\
\text { important } \\
\%\end{array}$ & $\begin{array}{c}\text { Not very } \\
\text { important } \\
\%\end{array}$ & $\begin{array}{c}\text { Not } \\
\text { important } \\
\text { at all } \\
\%\end{array}$ & $\begin{array}{c}\text { Don't } \\
\text { know } \\
\%\end{array}$ & $\begin{array}{c}\text { Refused } \\
\%\end{array}$ \\
\hline $\begin{array}{l}\text { A. Portable, so if you leave } \\
\text { one job you can take the } \\
\text { money and account with you } \\
\text { to your next job }\end{array}$ & 72 & 23 & 3 & 2 & $<1$ & 0 \\
\hline $\begin{array}{l}\text { B. Set up such that } \\
\text { contributions are automatically } \\
\text { taken from each paycheck } \\
\text { before taxes }\end{array}$ & 54 & 37 & 5 & 3 & 1 & 0 \\
\hline $\begin{array}{l}\text { C. Voluntary, so participants } \\
\text { are not required to make } \\
\text { contributions }\end{array}$ & 52 & 37 & 7 & 3 & 1 & 0 \\
\hline $\begin{array}{l}\text { D. Available to all employees } \\
\text { who do not have a way to } \\
\text { save for retirement at work, } \\
\text { including those who work for } \\
\text { small businesses }\end{array}$ & 62 & 32 & 3 & 2 & 1 & 0 \\
\hline
\end{tabular}




\section{AARP}

12. Americans are more likely to save for retirement when they can do so out of their regular paycheck at work. Yet many workers do not have access to a workplace retirement savings plan, especially those that work at small businesses. Thinking about this, do you agree or disagree with the following statement: "Arizona elected officials should support legislation that makes it easier for all workers to save for retirement out of their regular paycheck." Do you agree or disagree with this statement? (And is that strongly or somewhat?)

\begin{tabular}{|c|l|}
\hline$\%$ & $\mathrm{n}=317$ \\
\hline 56 & Strongly agree \\
\hline 32 & Somewhat agree \\
\hline 5 & Neither agree not disagree (DO NOT READ) \\
\hline 3 & Somewhat disagree \\
\hline 2 & Strongly disagree \\
\hline 1 & Not sure/ Don't know [DO NOT READ] \\
\hline 0 & Refused [DO NOT READ] \\
\hline
\end{tabular}

13. Thinking about the many concerns and issues that workers and employers are facing today related to the impact of the COVID-19 pandemic, do you agree or disagree that access to a workplace savings program is important for employees of small businesses and sole business owners in Arizona? (Is that strongly or somewhat?)

\begin{tabular}{|c|l|}
\hline$\%$ & $\mathrm{n}=317$ \\
\hline 52 & Strongly agree \\
\hline 39 & Somewhat agree \\
\hline 5 & Neither agree not disagree (DO NOT READ) \\
\hline 2 & Somewhat disagree \\
\hline 1 & Strongly disagree \\
\hline 2 & Not sure/ Don't know [DO NOT READ] \\
\hline 0 & Refused [DO NOT READ] \\
\hline
\end{tabular}

Thank you. Now, I just have a few more questions on how the Coronavirus pandemic has impacted your finances.

14. Has your household income declined since the coronavirus outbreak?

\begin{tabular}{|c|l|}
\hline$\%$ & $\mathrm{n}=317$ \\
\hline 69 & Yes \\
\hline 28 & No \\
\hline 4 & Not sure/ Don't know [DO NOT READ] \\
\hline 0 & Refused [DO NOT READ] \\
\hline
\end{tabular}




\section{AARP}

15. At any time since March of 2020, were you or anyone in your household laid off or furloughed from a job because of the coronavirus outbreak?

\begin{tabular}{|c|l|}
\hline$\%$ & $\mathrm{n}=317$ \\
\hline 54 & Yes \\
\hline 45 & No \\
\hline 1 & Not sure/ Don't know [DO NOT READ] \\
\hline 0 & Refused [DO NOT READ] \\
\hline
\end{tabular}

16. And at any time since March of 2020, have you or anyone in your household had to take a cut in pay at work due to reduced hours?

\begin{tabular}{|c|l|}
\hline$\%$ & $\mathrm{n}=317$ \\
\hline 66 & Yes \\
\hline 33 & No \\
\hline 1 & Not sure/ Don't know [DO NOT READ] \\
\hline 0 & Refused [DO NOT READ] \\
\hline
\end{tabular}

17. [IF 8a/b/c=YES] Prior to the coronavirus outbreak, approximately what percent of your total income were you saving on average each month in retirement plans, such as a $401 \mathrm{k}$, IRA, or another retirement plan? [READ LIST]

\begin{tabular}{|c|l|}
\hline$\%$ & $\mathrm{n}=248$ \\
\hline 3 & $0 \%$ \\
\hline 14 & $1 \%$ to $5 \%$ \\
\hline 22 & $6 \%$ to $10 \%$ \\
\hline 21 & $11 \%$ to $15 \%$ \\
\hline 13 & $16 \%$ to $20 \%$ \\
\hline 24 & More than $20 \%$ \\
\hline 3 & Not sure [DO NOT READ] \\
\hline 1 & Refused [DO NOT READ] \\
\hline
\end{tabular}

18. [IF $8 \mathrm{a} / \mathrm{b} / \mathrm{c}=\mathrm{YES}$ ] Since the coronavirus outbreak, approximately what percent of your total income are you saving now in retirement plans, such as a 401k, IRA, or another retirement plan? [READ LIST]

\begin{tabular}{|c|l|}
\hline$\%$ & $\mathrm{n}=248$ \\
\hline 6 & $0 \%$ \\
\hline 19 & $1 \%$ to $5 \%$ \\
\hline 21 & $6 \%$ to $10 \%$ \\
\hline 22 & $11 \%$ to $15 \%$ \\
\hline 18 & $16 \%$ to $20 \%$ \\
\hline 9 & More than $20 \%$ \\
\hline 3 & Not sure [DO NOT READ] \\
\hline 1 & Refused [DO NOT READ] \\
\hline
\end{tabular}




\section{AARP'}

19. [All] Have your attitudes about saving for your retirement changed since the coronavirus outbreak in the U.S.?

\begin{tabular}{|l|l|}
\hline$\%$ & $\mathrm{n}=317$ \\
\hline 60 & Yes \\
\hline 37 & No \\
\hline 2 & Not sure [DO NOT READ] \\
\hline 1 & Refused [DO NOT READ] \\
\hline
\end{tabular}

20. [IF Q8a/b/c=YES] What actions have you taken since the coronavirus outbreak in the U.S. in regard to your savings in retirement plan(s)? [READ LIST; ACCEPT MULTIPLE RESPONSES EXCEPT FOR 1-2 (MUTUALLY EXCLUSIVE - CANNOT SELECT BOTH AND 8 (CANNOT SELECT 8 AND ANY OTHER OPTIONS] [RANDOMIZE ORDER OF 1-6

\begin{tabular}{|c|l|}
\hline$\%$ & $\mathrm{n}=248$ \\
\hline 34 & Re-allocated money to different investment(s) within your plan \\
\hline 26 & Withdrew some money early \\
\hline 24 & Took a loan against your 401(k) or other retirement savings account \\
\hline 23 & Reduced the amount you are contributing \\
\hline 22 & Are no longer contributing \\
\hline 13 & Withdrew all money early \\
\hline 1 & Other (Please specify) \\
\hline 25 & You have not taken any action with your retirement savings [Anchor] \\
\hline 1 & Don't know or refused (VOL) \\
\hline
\end{tabular}

21. [AIl] What financial steps, if any, are you taking as a result of the coronavirus outbreak? [READ LIST, ALLOW MULTIPLE RESPONSES FOR 1-8; RANDOMIZE ORDER OF 1-7]

\begin{tabular}{|c|l|}
\hline$\%$ & $n=317$ \\
\hline 47 & Reducing nonessential spending \\
\hline 38 & Postponing large financial decisions (e.g. buying a house, furniture, car) \\
\hline 37 & Building up an emergency savings fund \\
\hline 37 & Finding more affordable options (e.g. health, car, or life insurance) \\
\hline 24 & Reallocating what would have been savings for retirement to an emergency fund \\
\hline 21 & $\begin{array}{l}\text { Postponing payments to companies or lenders who are offering a grace period or } \\
\text { relief }\end{array}$ \\
\hline 17 & Buying more items on credit \\
\hline 0 & Other (Please specify) \\
\hline 10 & None of the above [Anchor] \\
\hline 1 & Don't know or refused (VOL) \\
\hline
\end{tabular}




\section{AARP}

The following questions are for classification purposes only and will be kept entirely confidential.

D1. [All] Do you do something to earn extra money that is not your main source of income?

\begin{tabular}{|c|l|}
\hline$\%$ & $\mathrm{n}=317$ \\
\hline 62 & Yes \\
\hline 37 & No \\
\hline 1 & Not sure/ Don't know [DO NOT READ] \\
\hline 0 & Refused [DO NOT READ] \\
\hline
\end{tabular}

D2. [All] What is the highest level of education that you completed? (READ LIST)

\begin{tabular}{|c|l|}
\hline$\%$ & $\mathrm{n}=317$ \\
\hline 3 & $0-12$ th grade (no diploma) \\
\hline 23 & High school graduate (or equivalent) \\
\hline 12 & Post-high school education (no degree) \\
\hline 17 & 2-year college degree \\
\hline 13 & 4-year college degree \\
\hline 7 & Post-graduate study (no degree) \\
\hline 26 & Graduate or professional degree \\
\hline$<1$ & Not sure/ Don't know [DO NOT READ] \\
\hline 0 & Refused [DO NOT READ] \\
\hline
\end{tabular}

D3. [All] What is your current marital status? Are you currently...? (READ LIST)

\begin{tabular}{|c|l|}
\hline$\%$ & $\mathrm{n}=317$ \\
\hline 66 & Married \\
\hline 12 & Not married, living with your partner \\
\hline 1 & Separated \\
\hline 4 & Divorced \\
\hline 1 & Widowed \\
\hline 16 & Single and never been married \\
\hline 0 & Not sure/ Don't know [DO NOT READ] \\
\hline 0 & Refused [DO NOT READ] \\
\hline
\end{tabular}

D4. IF AGES 40 - 64 AND D3 = A, ASK: "Are you or your spouse currently a member of A-A-R-P?" IF AGES 40 - 64 AND D3 = 2, ASK: "Are you or your partner currently a member of A-A-R-P?" OTHERWISE, IF AGES 50 - 64, ASK: “Are you currently a member of A-A-R-P?"]

\begin{tabular}{|c|l|}
\hline$\%$ & $\mathrm{n}=161$ \\
\hline 25 & Yes \\
\hline 75 & No \\
\hline 0 & Not sure/ Don't know [DO NOT READ] \\
\hline 0 & Refused [DO NOT READ] \\
\hline
\end{tabular}




\section{AARP}

D5. [All] Are you of Hispanic, Spanish, or Latino origin or descent?

\begin{tabular}{|c|l|}
\hline$\%$ & $\mathrm{n}=317$ \\
\hline 100 & Yes \\
\hline 0 & No \\
\hline 0 & Not sure/ Don't know [DO NOT READ] \\
\hline 0 & Refused [DO NOT READ] \\
\hline
\end{tabular}

D6. [All] What is your race? Are you...? (READ LIST)

\begin{tabular}{|c|l|}
\hline$\%$ & $\mathrm{n}=317$ \\
\hline 74 & White or Caucasian \\
\hline 16 & Black or African American \\
\hline$<1$ & Asian \\
\hline 2 & American Indian or Alaska Native \\
\hline 0 & Native Hawaiian or other Pacific Islander \\
\hline 7 & Other [RECORD ANSWER] \\
\hline 1 & Not sure/ Don't know [DO NOT READ] \\
\hline 1 & Refused [DO NOT READ] \\
\hline
\end{tabular}

D7. [AIl] Do you consider yourself to be a....? [RANDOMIZE A-C; read D last]

\begin{tabular}{|c|l|}
\hline$\%$ & $\mathrm{n}=317$ \\
\hline 36 & Democrat \\
\hline 43 & Independent \\
\hline 19 & Republican \\
\hline$<1$ & Something else [RECORD ANSWER] \\
\hline 1 & Not sure/ Don't know [DO NOT READ] \\
\hline$<1$ & Refused [DO NOT READ] \\
\hline
\end{tabular}

D8. [All] How would you characterize your political views? (READ LIST)

\begin{tabular}{|c|l|}
\hline$\%$ & $\mathrm{n}=317$ \\
\hline 19 & Very conservative \\
\hline 20 & Somewhat conservative \\
\hline 33 & Moderate \\
\hline 13 & Somewhat liberal \\
\hline 9 & Very liberal \\
\hline 2 & None of the above/ something else [DO NOT READ] \\
\hline 3 & Not sure/ Don't know [DO NOT READ] \\
\hline 1 & Refused [DO NOT READ] \\
\hline
\end{tabular}




\section{AARP}

D9. [All] Do you own or rent your primary residence?

\begin{tabular}{|c|l|}
\hline$\%$ & $\mathrm{n}=317$ \\
\hline 62 & Own \\
\hline 36 & Rent \\
\hline 2 & {$[$ [DO NOT READ] Something else [RECORD ANSWER] } \\
\hline 0 & Not sure/ Don't know [DO NOT READ] \\
\hline 0 & Refused [DO NOT READ] \\
\hline
\end{tabular}

D10. [All] We realize income is a private matter and so rather than ask you anything specific about your income, l'd like to ask you to please stop me when I get to the category that includes your household's income before taxes in 2020. Was it...? [INSERT AND READ EACH ANSWER CATEGORY] [CONFIRM INCOME BREAKS]

\begin{tabular}{|c|l|}
\hline$\%$ & $\mathrm{n}=317$ \\
\hline 3 & Less than $\$ 10,000$ \\
\hline 5 & $\$ 10,000$ to less than $\$ 20,000$ \\
\hline 9 & $\$ 20,000$ to less than $\$ 30,000$ \\
\hline 10 & $\$ 30,000$ to less than $\$ 40,000$ \\
\hline 9 & $\$ 40,000$ to less than $\$ 50,000$ \\
\hline 7 & $\$ 50,000$ to less than $\$ 60,000$ \\
\hline 5 & $\$ 60,000$ to less than $\$ 75,000$ \\
\hline 33 & $\$ 75,000$ to less than $\$ 100,000$ \\
\hline 4 & $\$ 100,000$ to less than $\$ 125,000$ \\
\hline 6 & $\$ 125,000$ to less than $\$ 150,000$ \\
\hline 2 & $\$ 150,000$ to less than $\$ 200,000$ \\
\hline 1 & Not sure/ Don't know [DO NOT READ] \\
\hline 2 & Refused [DO NOT READ] \\
\hline
\end{tabular}

D12. [All] We would like to learn more about retirement savings issues among the LGBTQ community. Do you identify as a member of the LGBTQ community?

\begin{tabular}{|c|l|}
\hline$\%$ & $\mathrm{n}=317$ \\
\hline 10 & Yes \\
\hline 88 & No \\
\hline 2 & Prefer not to say (VOL) \\
\hline
\end{tabular}

